\title{
Intuition and rationality in intrapreneurship and innovation outputs: The case of health professionals in primary health
} care

\section{Carla S. Marques ${ }^{1}$ - Cândido Lopes ${ }^{2}$ - Vitor Braga ${ }^{3}$. Vanessa Ratten ${ }^{4}$. Gina Santos ${ }^{5}$}

Accepted: 11 July 2021 / Published online: 17 August 2021

(c) The Author(s), under exclusive licence to Springer Science+Business Media, LLC, part of Springer Nature 2021

\begin{abstract}
The aim of this article is to explore the role of cognitive styles and intrapreneurship in health professionals' innovation outputs, as well the mediated effect of intrapreneurship between cognitive styles and innovation output. This study used the survey method of data collection, through a self-administered questionnaire. Partial least square structural equation modelling method was used to analyse the result of the sample of 209 professionals of primary health care providers in Northern Portugal. Our findings reveal that cognitive style plays a significant role in intrapreneurship and innovation outputs, which are mediated by intrapreneurship. In particular, health care professionals with the rational cognitive style are likely to be more of a intrapreneur and innovative as compared to those with a intuitive cognitive style. Promoting intrapreneurship is crucial for successful innovation outputs. This study reveals that an understanding of the cognitive style of the health care professionals can help managers allocate appropriate individuals to different healthcare tasks. Our primary contribution to theory has been to highlight the importance of cognitive styles in intrapreneurship and innovation within the context of primary health care organizations.
\end{abstract}

Keywords Cognitive styles · Entrepreneurial decision making · Intrapreneurship · Innovation outputs $\cdot$ Health professionals

Vanessa Ratten

v.ratten@latrobe.edu.au

Extended author information available on the last page of the article 


\section{Introduction}

The idea that innovation is relevant to create competitiveness in modern organizations has been commonly proven by several authors (e.g., Wojtczuk-Turek \& Turek, 2015; Zhang \& Bartol, 2010). Fostering intrapreneurial behaviors and practices has assumed prime importance in the strategies of many organizations where creating innovation is perceived as an important means of establishing and maintaining competitive advantage as well as a method for initiating corporate renewal (Russel, 1999). However, there is still a lack of understanding about different contextual and individual situations that influence the intrapreneurship-innovation link.

Innovations in healthcare are a critical issue in ensuring organisational efficiency and effectiveness in constantly changing healthcare environments, as in other industries (Yang et al., 2019). Health professionals need innovative approaches to meet the care needs of different patients (Machon et al., 2019). Innovative approaches are required in improving health, preventing diseases, implementing new treatments and providing safe and high-quality care services, these allowances are always essential, but at the present time of the COVID 19 pandemic they become much more relevant. Therefore, innovation should become a fundamental part of health professional practices at all levels, including primary health care.

It is important to understand what individual and organizational aspects can become a basis for innovative activities to be carried out in the healthcare workplace (Wojtczuk-Turek \& Turek, 2015). As for the individual aspects, for health professionals, the use of the intuitive or rational system, when faced with a certain clinical situation, depends on the complexity of the situation in relation to the professional's abilities, previous experiences and self-confidence (Allinson et al., 2000; Croskerry, 2009; Tay et al., 2016). The results of Allinson et al. (2000) study indicated that the cognitive perspective has the potential to make an important contribution to the study of entrepreneurship. More specifically, they refer to the possibility that further research into cognitive styles could provide a differentiated basis for identifying those individuals who have the potential to become successful entrepreneurs. Armstrong et al. (2011), in their review of the research on the influence of cognitive style on entrepreneurship, identify several insights relating to the impact of cognitive style on entrepreneurial action, creativity, and innovation.

Intrapreneurship is a subtype of entrepreneurship whose study has increased in the last two decades (Blanka, 2019) in order to understand its nature, background and implications in organizations (e.g., A ğca et al., 2012; Gawke et al., 2018). With respect to the intrapreneurial activities of the employee, the current literature is scarce and fragmented (Blanka, 2019). In the health sector, there are some studies on individual and organizational factors that influence intrapreneurship (e.g., Gawke et al., 2018; Lages et al., 2017; Marques et al., 2019). However, to the best of our knowledge, no studies have so far studied the role of cognitive styles in intrapreneurship, in any sector of activity. In order to bridge this gap and based on the study by Armstrong et al. (2011), this study aims to explore the role of cognitive styles and intrapreneurship in health professionals' innovation outputs, as well the mediated 
effect of intrapreneurship between cognitive styles and health professionals' innovation output.

In light of the above discussion, the authors were motivated to develop the current study and address some major research gaps pertaining to the concept of intrapreneurship. First, it was observed that the existing empirical studies on intrapreneurship have primarily focussed on examining its various organizational-level antecedents and outcomes such as organizational support (e.g., Covin \& Slevin, 1991; Lages et al., 2017). However, research examining its relationship with individuallevel variables such as cognitive styles have not received much attention. We believe that examining such relationships are important because cognitive styles have an intertwined relationship with intrapreneurial decision-making and innovative performance of the individuals. Second, the current study also addresses some theoretical gaps in the literature. It extends the discussion on the role of cognitive styles on intrapreneurship and trying to establish the mediating role of intrapreneurship in the relationships between cognitive styles and innovation outputs. Prior studies have not examined the role of cognitive styles in the context of intrapreneurship. Finally, the sector chosen for the study, i.e. primary health care further enhances the novelty of the research. No such research on intrapreneurship has explored in the context of primary health sector. The bibliometric analysis carried out by Galván et al. (2021) showed the existence of few studies on intrapreneurship, suggesting the contribution of new models in specific sectors and territories is required. They also raise the need to link the term with other areas of knowledge, such as psychology, specifically with regard to the measurement of intrapreneurship at the individual level by addressing the following question: what are the conditions that lead employees of a given organization or sector to develop intrapreneurial behavior and to propose and carry out new business ideas from the organization for which they work? This includes the areas of public administration, like primary health care, and new psychological predictors, like cognitive styles. Therefore, in this study our research question is: What is the role of cognitive styles and intrapreneurship in health professionals' innovation outputs?

This article is divided into five sections. The next section discusses the theoretical foundation of the topics addressed that support the research hypotheses for our conceptual research model. In the following section, the methodology used in this research is explained. In the fourth section the main results are presented, namely the characterization of the sample, the validation of the measurement instrument and the structural equations model based on the conceptual research model. In the fifth section, conclusions, discussion of results, implications of the study and limitations of the investigation are presented.

\section{Theoretical background and hypotheses}

\section{Cognitive styles}

Cognitive styles also named mental models, take into account the information and the experience of each individual. Organizations, in any industry, increasingly 
demand greater input from their employees; proactivity is required and, together with managers in order to identify market opportunities and threats, as well as being able to make decisions. According to Tay et al. (2016) decision making is complex, using two types of cognitive operations, named as the intuitive and the rational system. The thinking process of the intuitive system is often described as a reflective system, which is "intuitive" and "experimental", which leads to an automated way of thinking. It is produced without much conscious effort and channels available information through a recognition of subconscious patterns based on similar past situations. When an individual is more dependent on the intuitive system, the accuracy of decision-making can be affected (Croskerry, 2009). However, there is evidence that the intuitive system is an indispensable element for health professionals' decision making (Tay et al., 2016). The rational system is more determined than the intuitive system, the latter is not necessarily less capable, on the contrary, complex cognitive operations eventually migrate from the rational system to the intuitive system (i.e., they become more automatic) as capacity and skills are accumulated (Moulton et al., 2007).

The rational system is the most intentional and analytical side of the cognitive process. It is grouped by logical judgment and a mental search for additional information acquired through past learning and experience (Croskerry, 2009). The data is then carefully organized, through a conscious application of the rules, making it a slower and cognitively more demanding process, but more likely to lead to better decisions - the rational system is usually involved when there is uncertainty, complexity or problems, and its results give little room for error, but there is time to think (Moulton et al., 2007). The thinking process of the rational system is slow, requiring significant cognitive effort and, although it is less prone to errors, it is not infallible (Tay et al., 2016). The intuitive and rational systems thinking is useful in the right place and at the right time, in fact, they complement each other. Together, they promote greater thinking, decision making and action efficiency, and help to organize thinking and uncertainties (Quirk, 2006).

Cognitive styles are an important factor of individual behaviour in management (Armstrong et al., 2011) and in the way individuals generate ideas and implement them, and there is an increased interest in their study in this area (Alnuaimi et al., 2017). Allinson et al. (2000) results indicate that the cognitive perspective has the potential to make an important contribution to the study of entrepreneurship. Over the past five years, some studies have emerged that relate cognitive styles to entrepreneurship (e.g., Adomako et al., 2016; Deprez et al., 2019; Estelami \& Nejad, 2017; Franić \& Drnovšek, 2019; Molaei et al., 2014; Randerson et al., 2016), and to innovation (e.g., Batra \& Vohra, 2016; Alnuaimi et al., 2017; Aggarwal \& Woolley, 2019; Lomberg et al., 2017). Before that Corbett and Hmielski (2007) refers the emerging view of entrepreneurial cognition suggests that an understanding of the mental processes of entrepreneurs will enable researchers to build a well-grounded foundation toward systematically explaining the individual's role within the process of entrepreneurship.

Cognitive experiential self-theory (CEST) explains the presence of intuitive and rational thinking styles in managerial cognition (Epstein et al., 1996). This theory shows how the intuitive cognitive mode is associated with affect and operates at an 
automatic, preconscious level, and the rational mode is affect free and operates at a conscious level. In this study, we indicate that intuition involves very rapid and nonconscious decision making and rationality refers to slow and conscious decision making. The bipolar nature of conceptualizing and measuring cognitive style also helps to capture the dialectic in solving problems and ways to resolve conflict when dealing with an experience; such conceptualization helps to develop more accurate understanding of meaning making processes for an individual.

In the scientific community there are differences of opinion regarding the treatment of cognitive styles as separate scales or as opposite poles of the same dimension (Cools \& Broeck, 2007). Currently the convergence of ideas goes in the sense that cognitive styles can be placed in a spectrum (Estelami \& Nejad, 2017) in a continuous variation from intuitive to analytical (Molaei et al., 2014), which varies according to tasks or situations in which the individual finds himself. At one pole of the spectrum are exclusively analytical and at the other exclusively intuitive individuals, and many individuals have styles that are somewhere between these two extremes (Estelami \& Nejad, 2017). The use of the intuitive or rational system, when it comes to thinking and acting in a particular clinical situation, depends on the complexity of the situation in relation to the capabilities of health professionals, past experiences and self-confidence (Tay et al., 2016). Taking these statements in mind we decided to use the Allinson and Hayes (1996) Cognitive Style Index (CSI), which is a twodimensional measuring instrument: intuitive cognitive style and rational cognitive style. The evaluation of the cognitive styles of managers, leaders and employees has begun to be carried out, albeit sparingly, in health studies, mainly at the level of the evaluation of the cognitive style in decision making (e.g., Djulbegovic et al., 2014) and personal motivations and characteristics (e.g., Parker-Tomlin et al., 2018). There are no studies that linked cognitive styles to intrapreneurship and innovation of health professionals.

\section{Intrapreneurship}

The different approaches to studying and defining intrapreneurship are not really contradictory because corporate entrepreneuring is a multidimensional phenomenon, incorporating individual, organizational, and environmental elements (Russel, 1999). The primary focus of this paper is on individual influences on the process of corporate entrepreneurship. In order to accommodate this perspective, intrapreneurship is defined as "a process whereby employee(s) recognize and exploit opportunities by being innovative, proactive and by taking risks, in order for the organization to create new products, processes and services, initiate self-renewal or venture new businesses to enhance the competitiveness and performance of the organization" (Neessen et al., 2019 , p.551). This concept thus gives relevance not only to organizational aspects, but also to individual aspects of the employee.

There are different conceptualizations of intrapreneurship. According to Antoncic and Hisrich (2001) at the organizational level it can be evaluated in four dimensions: creation of new business within the company; innovation (products, services and technologies); self-renewal (strategy reformulation, reorganization and changes in 
the company) and proactivity (search for competitiveness which includes initiative, risk, daring and aggressiveness). There is also a second conceptualization which focuses on the gains of intrapreneurship from employees to employers (Gawke et al., 2019). However, more recently, a third conceptualization of intrapreneurship has emerged: this results from a strategic behavior (creating, adding or investing resources in new businesses to the organization) and strategic renewal (seeking advantages to renew or enhance products, services, methods or strategies) (Gawke et al., 2018, 2019). The great difference between them is that the former focus on the organizational vision and the latter on the employee's vision and results obtained by them (Gawke et al., 2019). This study explores the intrapreneurship-innovation link, thus, although the innovation dimension is associated with the conceptualisation of intrapreneurship at the organisational level, we find that the conceptualisation presented by Gawke et al. (2019) places the employee as the most important element of intrapreneurship. This means that they show that they can contribute to organisational innovation through seeking advantages to renew or enhance products, services, methods or strategies.

Intrapreneurship is gaining traction in organizations to buckle up for the dynamic business environment (Pandey et al., 2020). Several studies have been given increasing attention to intrapreneurship because it has a positive effect on the survival, growth, profit and renewal of organizations (e.g., Cadar \& Badulescu, 2015; Reuther et al., 2017; Zahra, 1995). Intrapreneurship is fundamental for the survival of organizations through constant innovations that convert, among other options, in the development of new products and services or in the conquest of new markets (Marques et al., 2019). According to Marques et al. (2018) organizations that provide health services, particularly in countries where the public sector plays a vital role, intrapreneurship has become increasingly important.

Employees need to adopt "innovative" and "differentiating" roles, instead of passively receiving orders, exchanges and products (Bowen, 2016). Over time, the role of employees in organizations has changed. Decision-making processes have become more decentralized and employees have gained more responsibility (Caputo \& Pellegrini, 2019; Foss \& Klein, 2015).

The entrepreneurial decision-making style can be analysed by taking and intrapreneurial perspective (Tognazzo et al., 2020). Research by Neessen et al. (2019) suggests that the intrapreneurial behaviour of employees has become strategically important for the organizations' performance. Entrepreneurs are individuals able to identify and/ or create opportunities and innovation, using resources that allow extracting the maximum benefits from such innovations (Gartner \& Shane, 1995).

The decision making style of intrapreneurs is different due to institutional factors affecting their behaviour. The discussion on intrapreneurship is incomplete without clearly distinguishing the 'intrapreneurs' from the 'entrepreneurs'. Marques et al. (2019) found that there are differences between entrepreneurs' and intrapreneurs' profiles. Entrepreneurs are considered agents of change, innovators who produce new products or identify new markets, combine ways that lead to new resources, achieve competitive advantage and create changes in the market competitiveness rules (Caputo \& Pellegrini, 2019). In contrast, intrapreneurs seek to change their 
organizations and innovate within that context, but it requires an organizational culture and environment that encourages successful entrepreneurship.

Allinson et al. (2000) were among the first to study the relationship between cognitive styles and entrepreneurship, since cognitive styles are essential in explaining entrepreneurial behaviour (Randerson et al., 2016). Entrepreneurial cognition is the study of the mental models of entrepreneurs and how the entrepreneurial process and its results are related to psychological traits (Chen et al., 2015). It is on individual behaviour that the activity and entrepreneurship of an organization depends, so the study of the relationship of cognitive styles as the primary antecedent of intrapreneurship is vital. For Pandey et al. (2020) intrapreneurship is on the rise in organisations, with these researchers claiming that intrapreneurship increases positivity at work enabling employees to perform better. The results of their study highlight the existence of positive relationships between intrapreneurship, cognitive styles and work engagement.

Based on these arguments, the following hypothesis are postulated:

$\boldsymbol{H}_{1}$ : Health professionals' rational cognitive style has a positive influence on intrapreneurship.

$\boldsymbol{H}_{2}$ : Health professionals' intuitive cognitive style has a positive influence on intrapreneurship.

\section{Innovation outputs}

Innovation can be considered to be the result of "a systematic effort and a high degree of organization" (Drucker, 2014). It can be described as the willingness and interest for looking for new ways of acting, and this conceptualization does not imply the introduction of innovative products, but a preference for being committed and involved in creative and experimental processes (Rauch, 2010).

Innovation in the primary health care sector refers to the act or process of developing new ideas and devices that imply new methods of providing healthcare. Innovation is not only about reforming the work at one single primary health care organization, but it is about developing services and new work methods that can be more broadly diffused and implemented at several primary health care organizations (Côté-Boileau et al., 2019). Innovations should lead to higher efficiency, be safe and convenient for patients, therefore must be sustainable over time, consequently contributing to an improved environment, as well as economically sound and supportive of the society (Emilsson et al., 2020).

Thus, innovation activities are highly dependent on the individuals who carry them out, either as entrepreneurs or as employees (Rufaidah, 2017). In the development of innovative behaviour, during the implementation phase, the biggest challenge is to overcome obstructions, barriers and resistance (Howell et al., 2005), this can only be achieved by adapting the idea or implementation plans until the product, service or processes are perfected and used in the organization, thus the results or innovation outputs are achieved (Lukeš \& Stephan, 2017). 
Lukeš and Stephan (2017) explain innovation outputs as achieved changes, i.e., the implementations of new ideas accomplished to change products, services or processes within the organization. In this context, innovative employees achieve innovative results, such as inventions, new products, new services or new models. Researchers like Gawke et al. (2018) mentioned that employees' intrapreneurship can have beneficial results for their well-being through their potential to increase personal resources, which, in turn, increase the work involvement levels and maintain these levels effectively. This means there is some degree of autonomy and self-discretion associated with being an intrapreneur that leads to better overall results. This is supported by Letsie (2017) who found that intrapreneurial nurses are compared to front line runners, because they develop, promote and offer innovative care, transforming the workplace atmosphere or culture by improving internal processes. Some studies explore this intrapreneurship-innovation link. For example, Marvel et al. (2007) showed that intrapreneurial employees (i.e., employees who actively engage in venture and strategic renewal behaviors) in the technical sector were responsible for the creation, promotion, and implementation of several breakthrough innovations for their organization. Moreover, Camelo-Ordaz et al. (2012) reported similar results in their study among intrapreneurial employees in the creative industry, as well Wan et al., (2020a, 2020b) in platform enterprises.

Based on the above discussion, the following hypothesis about the relationship between intrapreneurship and cognitive styles can be stated:

\section{$\boldsymbol{H}_{3:}$ Health professional's intrapreneurship has a positive influence on innova-} tion outputs.

It has been described in the literature that the innovative behavior of each employee is a focus of innovation and intrapreneurship (Lukes \& Stephan, 2017) and that the need to foster competitiveness in organizations leads to the cognitive approach (cognitive styles) of employees being essential to foster innovation, achieving better results (Alnuaimi et al., 2017).

Some researchers argued that cognitive styles would be correlated with the propensity to be innovative (Armstrong et al., 2011; Batra \& Vohra, 2016). Building on the above discussion, it is profound that the cognitive styles may boost intrapreneurship. Likewise, intrapreneurship was found to serve as significant predictor of innovation outputs (e.g., Gawke et al., 2018; Pandey et al., 2020). Thus, intrapreneurship could serve as a potential mediator on the relationship between cognitive styles and innovation outputs. A mediator is defined as an intervening variable that serves as a channel over which an independent variable is capable of impacting a dependent variable (Hayes, 2009). As the two dimensions of cognitive styles (intuitive and rational) postulates a positive association with intrapreneurship (mediator) and the intrapreneurship (mediator) also postulates a positive association with innovation outputs (independent variable), then intrapreneurship could mediate the association between cognitive styles dimensions and innovation outputs. Thus, this study postulate that: 
$\boldsymbol{H}_{4 a}:$ Health professional's intrapreneurship mediates the relation between rational cognitive styles and innovation outputs

$\boldsymbol{H}_{4 b}$ : Health professional's intrapreneurship mediates the relation between intuitive cognitive styles and innovation outputs

The conceptual model was based on the EIS (Employee intrapreneurship measurement scale), developed by Gawke et al. (2019), and incorporating output innovation dimension of Lukeš and Stephan (2017) - the Innovation Support Inventory (ISI) — and Allinson and Hayes (1996) CSI (Cognitive Styles Index), for cognitive styles.

\section{Methodology}

In order to empirically evaluate the model in Fig. 1, a questionnaire was developed and applied to health professionals in primary health care sector, at ACES Tâmega III- Vale Sousa Norte, in Portugal. The questionnaire was structured in four parts: 1) Intrapreneurship, EIS was used (Employee intra-entrepreneurship measurement scale-Gawke et al., 2019), containing 17 items, venture behaviour (8 items) and strategic renewal behaviour (9 items); 2.) Innovation outputs, the Innovation Support Inventory (ISI) by Lukeš and Stephan (2017) was used, containing 3 items; 3) Cognitive styles, Allinson and Hayes' (1996) CSI (Cognitive Style Index) was used, containing 20 items, rational style (10 items) and intuitive style (10 items); C) Sociodemographic data, containing 10 questions. It was applied in June 2019, with 312 surveys distributed, with 209 valid responses (67\% response rate). The 40 questions that make up part $\mathrm{A}, \mathrm{B}$ and $\mathrm{C}$ of the questionnaire were closed multiple-choice questions, following a previously chosen scale: we used the Likert scale, ranging from 1 to 7 .

In order to validate the data, the existence of missing values and outliers was verified. Once the computer file was validated, we proceeded to statistical analysis and data interpretation with the support of the statistical software IBM SPSS 24 (Arbuckle, 2016) and SmartPLS 3.0 (Ringle et al., 2015).

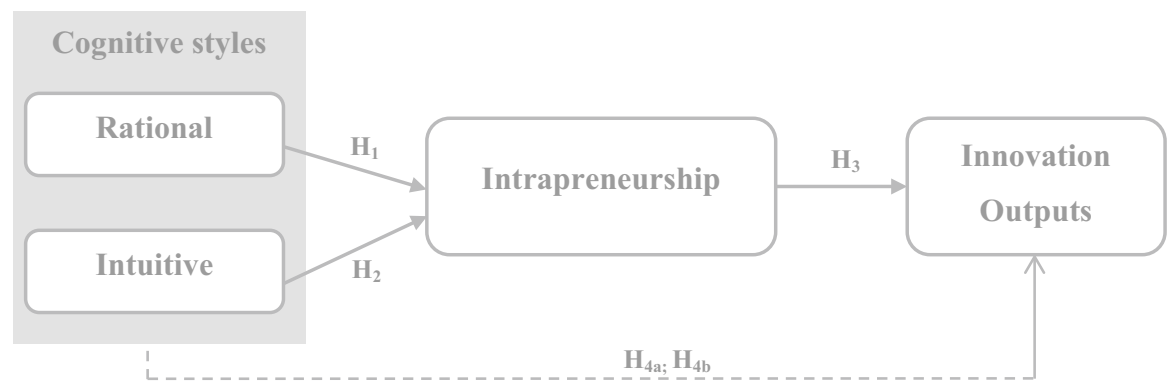

Fig. 1 Conceptual research model 
To test our hypotheses, as well as to compare the various variables, several tests were used throughout this study, within the scope of univariate analysis and multivariate analysis performed. The univariate (frequency analysis) and multivariate (analysis of structural equation models) technical analyses used will be described in the next chapter, anticipating the presentation of results for each of the statistical treatments performed.

Our sample includes $81.8 \%$ females, with the age group mostly represented being 36 to 45 years old (42.6\%). Most of the respondents are married or in a civil partnership $(81.3 \%)$ and have a higher education degree $(65.5 \%)$. Most of the respondents are nurses $(35.4 \%)$ followed by medical doctors $(21.1 \%)$. Almost all employees have a permanent link with the organization $(92.2 \%)$, with about half of them $(48.5 \%)$ holding 20 or more years of professional experience, which is $18.21 \pm 8,97$ years of average, ranging between 3 and 40 years. Only $6.2 \%$ of the sample are in management / coordination positions, and the type of bond that predominates is tenure $(82.8 \%)$. These respondents have $11-15$ years $(18.7 \%)$ and $21-25$ years $(17.2 \%)$ years of professional experience.

\section{Results: Intuition and rationality in intrapreneurship and innovation outputs of health professionals in primary health care}

\section{Evaluation of the psychometric properties of 2nd Order latent variable - intrapreneurship}

The psychometric characteristics related to the 2 nd order latent variable of Intrapreneurship took into account the recommendations mentioned by Hair et al. (2012), Hair et al. (2013) and Gefen et al. (2011), carrying out a Confirmatory Factorial Analysis and consequently evaluating the reliability of the constructs as well as the respective factorial validity, convergent validity and discriminant validity. As it can be seen in Table 1, the reliability of the constructs is met with the composite reliability (CR) values being all higher than $0.962(>0.70)$. All items of the different dimensions display factor loadings greater than 0.70 , so it is verified that there is factorial validity. The values of the average variance extracted (AVE) were found to be above 0.737 , so they fall within the recommended range $(>0.50)$, ensuring convergent validity (Bagozzi \& Yi, 1988).

Applying the Fornell-Larcker criterion, it was inferred that the values of the square root of the factors' VEM proved to be higher than the values of the correlation between them. After the determination of the scores of the sub-constructs mentioned above, these were used as manifest variables in the model to be tested.

\section{Measurement model (outer model)}

In order to evaluate the reliability of the constructs of the measurement model relative the, factorial validity, convergent validity and discriminant validity were 


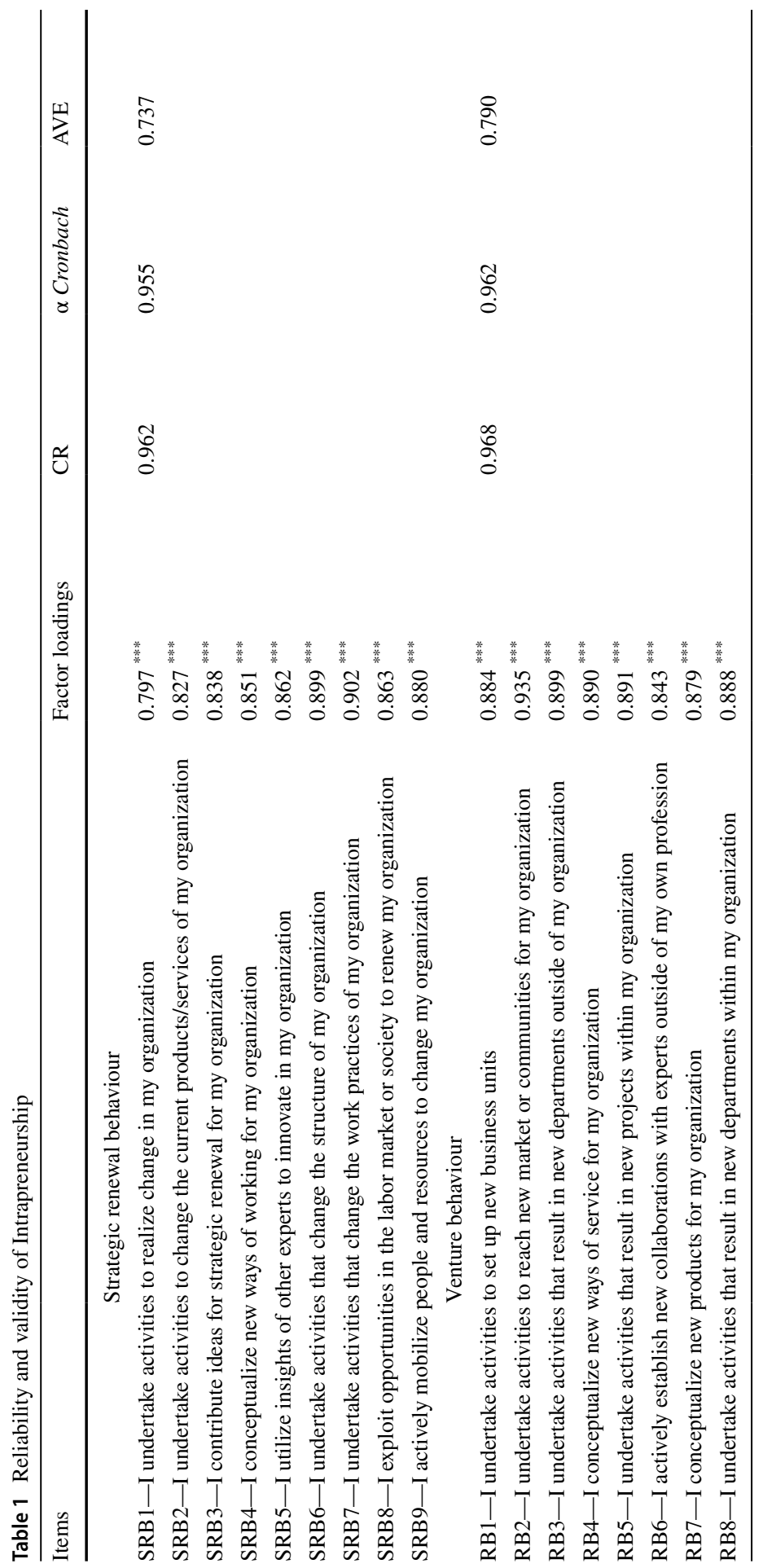




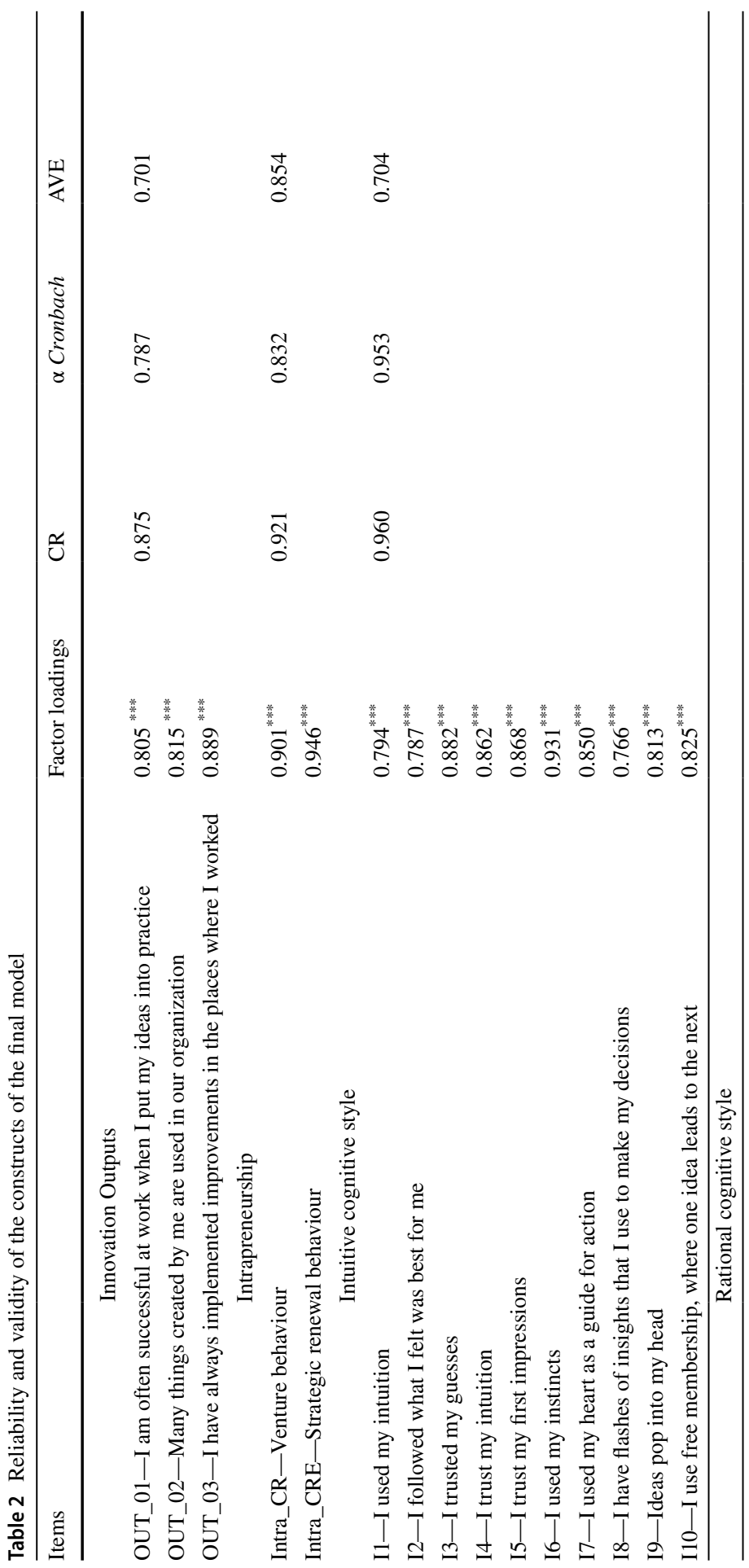




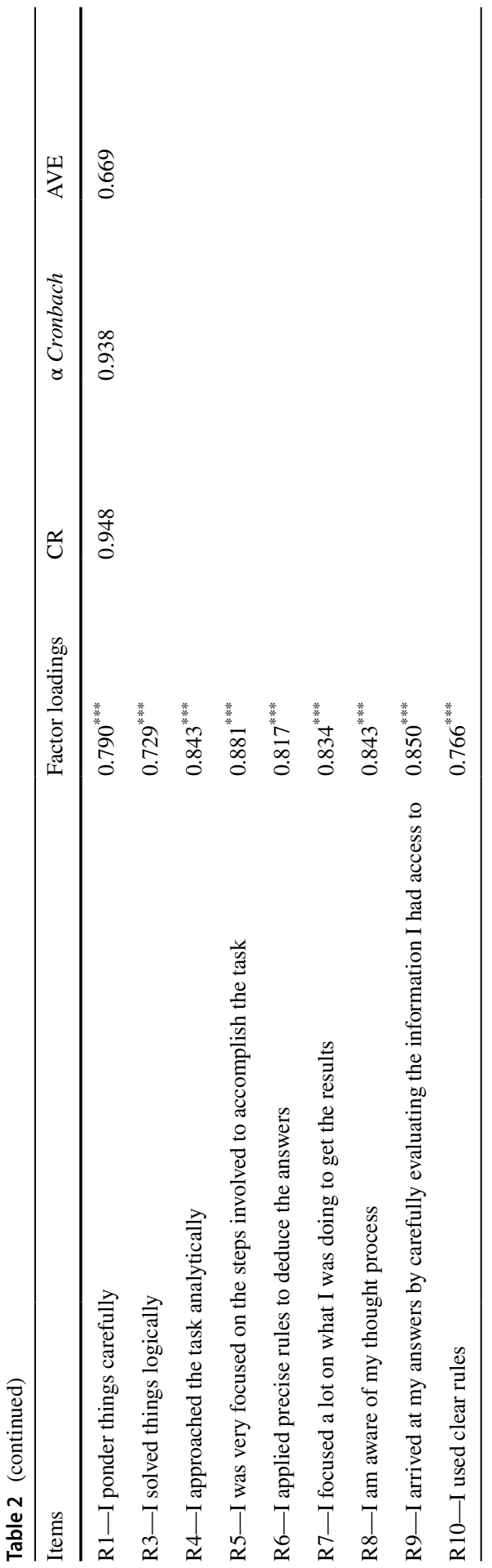


Table 3 Correlations and discriminant validity of the latent variables of the measurement model (FornellLarcker criterion)

\begin{tabular}{lllll}
\hline & $(1)$ & $(2)$ & $(3)$ & (4) \\
\hline (1) Intuitive cognitive style & $\mathbf{0 . 8 3 9}$ & & & \\
(2) Rational cognitive style & 0.330 & $\mathbf{0 . 8 1 8}$ & & \\
(3) Intrapreneurship & 0.311 & 0.343 & $\mathbf{0 . 9 2 4}$ & \\
(4) Innovation outputs & 0.340 & 0.515 & 0.523 & $\mathbf{0 . 8 3 7}$ \\
\hline
\end{tabular}

diagonally are the square root values of AVE

evaluated, following also the recommendations mentioned by Hair et al. (2012), Hair et al. (2013) and Gefen et al. (2011). It is important to note that one rational cognitive style factor loading showed a value slightly below 0.7 , "R2-I performed the task in a systematic way" (0.629), so we decided to remove the item. As it can be seen in Table 2, Innovation outputs has 3 manifest variables, Intrapreneurship has 2 manifest variables, the Intuitive cognitive style has 10 manifest variables and the Rational cognitive style 9 manifest variables. Also, based on Table 2, the reliability of the constructs was assessed with the minimum composite reliability value being $0.875(>0.70)$, thus ensuring the reliability of the construct. Factorial validity, on the other hand, was assessed through the analysis of factor loadings, which were higher than 0.7, thus confirming the factorial validity (Hair et al., 2011). Convergent validity was assessed taking into account the value of the average variance extracted (AVE), in all cases was greater than $0.669(>0.50)$ and was therefore guaranteed.

Discriminant validity was assessed using the Fornell-Larcker criterion (FornellLarcker, 1981) and, as it can be seen in Table 3, it the square root values of the factors AVE is significantly higher than their correlation, which happens for the various constructs under analysis, so there is discriminant validity.

\section{Structural model (inner model)}

The evaluation of the structural model and its predictive capacity was performed by the $\mathrm{R}^{2}$ of the endogenous latent variables (Chin, 1998), but also by the size of the $f^{2}$ effects (Cohen, 1988). As it can be inferred from Table 4, the $\mathrm{R}^{2}$ value of the Innovation outputs was 0.274 , and 0.162 for Intrapreneurship, so they were all above the acceptable cut-off point of 0.1 (Falk \& Miller, 1992). The effect size $(f$ ${ }^{2}$ ) complements $R^{2}$ and considers the relative impact of an exogenous variable, in particular on an endogenous variable through changes in $\mathrm{R}^{2}$ (Cohen, 1988). Cohen (1988) suggests $f^{2}$ values of $0.02,0.15$ and 0.35 for small, medium and large effects

Table 4 Size of the effects of the predictor variables on endogenous variables

\begin{tabular}{llll}
\hline Way & $\mathrm{R}^{2}$ & $f^{2}$ & Effect of $f^{2}$ \\
\hline Rational Cognitive Style $\rightarrow$ Intrapreneurship & 0,162 & 0,077 & Small \\
Intuitive Cognitive Style $\rightarrow$ Intrapreneurship & 0,162 & 0,053 & Small \\
Intrapreneurship $\rightarrow$ Innovation Outputs & 0,274 & 0,377 & Large \\
\hline
\end{tabular}




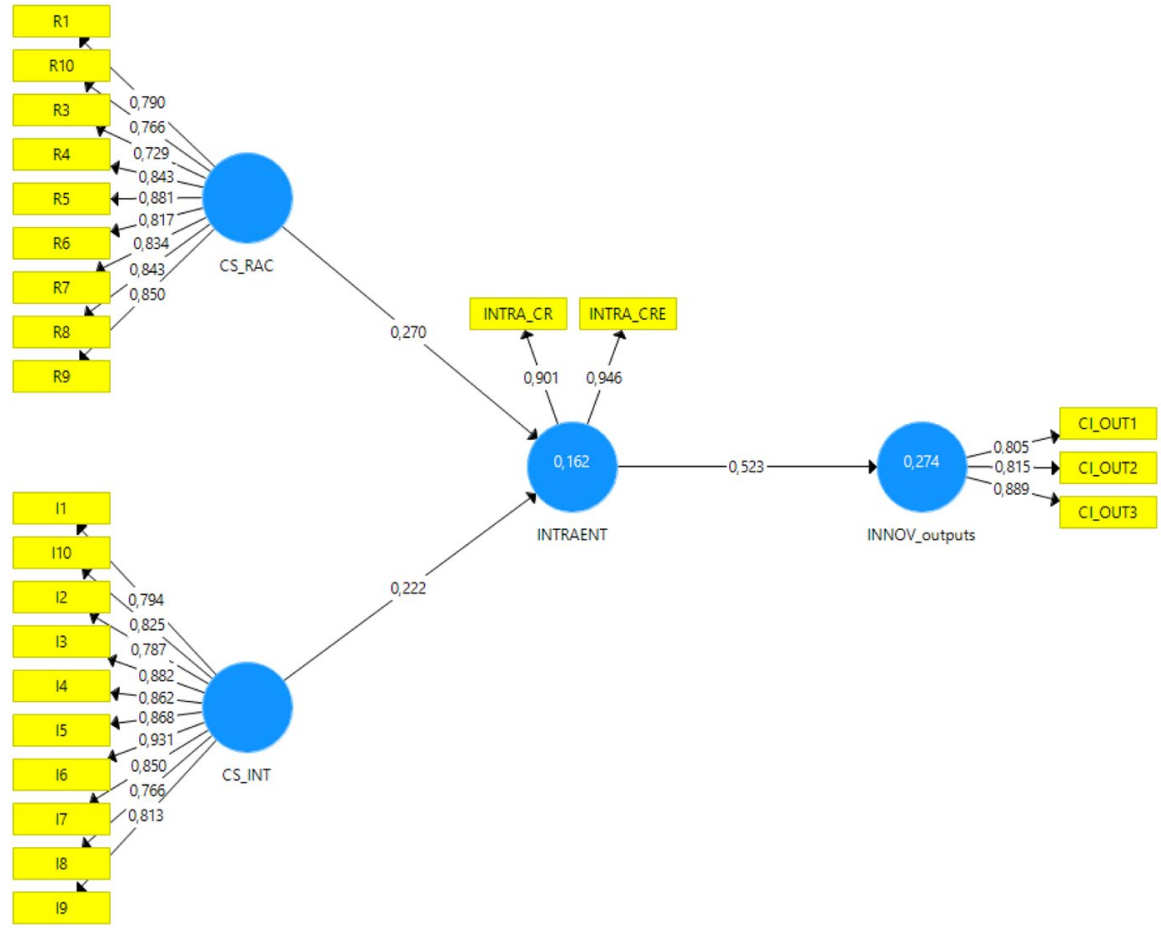

Fig. 2 Structural model with $\mathrm{R}^{2}$ values, regression coefficients and factor loadings

of predictive variables. Intrapreneurship showed a large effect on innovation outputs (0.377), while the cognitive styles presented a small effect, with $f^{2}$ values of 0.077 for the Rational Cognitive Style and 0.053 for the Intuitive Cognitive Style.

Likewise, the predictive relevance of the model was assessed using StoneGeisser's $Q^{2}$ statistics (Geisser, 1974; Stone, 1974). This procedure was carried

Table 5 Analysis of the hypotheses

\begin{tabular}{|c|c|c|c|}
\hline path & $\beta$ & $p$ & $\begin{array}{l}\text { Supported } \\
\text { hypothesis? }\end{array}$ \\
\hline H1: Rational Cognitive Style $\rightarrow$ Intrapreneurship & $0.270^{* * *}$ & $<0.001$ & Yes \\
\hline H2: Intuitive Cognitive Style $\rightarrow$ Intrapreneurship & $0.222^{* *}$ & 0.001 & Yes \\
\hline H3: Intrapreneurship $\rightarrow$ Innovation outputs & $0.523^{* * *}$ & $<0.001$ & Yes \\
\hline $\begin{array}{l}\text { H4a: Rational Cognitive Style } \rightarrow \text { Intrapreneurship } \rightarrow \text { Innovation } \\
\text { outputs }\end{array}$ & $0.141^{* *}$ & 0.001 & Yes \\
\hline $\begin{array}{l}\text { H4b: Intuitive Cognitive Style } \rightarrow \text { Intrapreneurship } \rightarrow \text { Innovation } \\
\text { outputs }\end{array}$ & $0.116^{* *}$ & 0.006 & Yes \\
\hline
\end{tabular}

$* p<0.010 ;{ }^{* *} p \leq 0.001 ;{ }^{* * *} p<0.001$ 
out following the resampling approach by blindfolding (considering 7 the default distance), thus examining the predictive power of the model (Tenenhaus et al., 2005). It was found that the value of $Q^{2}$ ranges between 0.126 in the Intrapreneurship construct and 0.183 in the Innovation outputs construct, which is why it is higher than zero in all constructs, thus suggesting the predictive relevance of the model (Chin, 1998). Figure 2 shows the SmartPLS output with the model and the control variables, representing the values of $\mathrm{R}^{2}$ within the endogenous latent variables, the regression coefficients of the structural model (inner model), as well as the representation of all items represented in the model with the respective factor loadings (outer model).

Table 5 shows the results of the research hypotheses. The structural model shows that the Rational cognitive style influences intrapreneurship $\left(\beta_{\text {Int.RCS }}=0.270\right.$; $\mathrm{p}<0.001)$ supporting hypothesis 1 . In turn, the Intuitive Cognitive Style impacts on Intrapreneurship $\left(\beta_{\text {Int.ICS }}=0.222 ; p=0.001\right)$ supporting hypothesis 2 . Intrapreneurship has shown to impact Innovation outputs $\left(\beta_{\text {Innov.Int }}=0.523 ; \mathrm{p}<0.001\right)$ supporting hypothesis 3 . It should be noted that Intrapreneurship mediates the relation between cognitive styles and innovation outputs, with a slightly higher effect on the relationship between rational cognitive style and innovation outputs $\left(\beta_{\text {oInnov.RCSInt }}=0.141\right.$; $\left.\mathrm{p}=0.001 \mathrm{vs} . \beta_{\text {oInnov.ICSIInt }}=0.116 ; \mathrm{p}=0.006\right)$, supporting hypothesis $4 \mathrm{a}$ and $4 \mathrm{~b}$.

\section{Discussion of results: Intuition and rationality in Intrapreneurship and innovation outputs of health professionals in primary health care}

We started the discussion of the results of the variables in this study by the cognitive styles, emphasizing that the cognition of the individual works as a spectrum, the cognitive style used (rational/intuitive) was variable and dependent on the task to be performed at a given time (Estelami \& Nejad, 2017; Molaei et al., 2014). Regarding the rational cognitive style, the results suggest that the primary health care professionals are focused on the steps involved to accomplish the task $(\lambda=0.881)$, carefully evaluating the available information $(\lambda=0.850)$, they approached the task analytically $(\lambda=0.843)$, and are aware of thought process $(\lambda=0.843)$. As for the intuitive cognitive style we notice that these professionals in the performance of their tasks use instinct $(\lambda=0.931)$, rely on their guesses $(\lambda=0.882)$, first impressions $(\lambda=0.868)$ and intuition $(\lambda=0.862)$. Considering the results $\mathrm{AVE}_{\mathrm{CS} \_\mathrm{IN}}=0.704$ and $\mathrm{AVE}_{\mathrm{CS} \_\mathrm{RAC}}=0.669$ we can see that the primary health care professional uses in practice a combination of the two cognitive styles, this cognitive flexibility between both styles is identified in some studies (e.g. Armstrong et al., 2011), with a slight tendency towards intuitive cognitive style, a result verified in other studies (e.g. Baldacchino, 2019). These results can be justified by the nature of their functions, as first line health professionals, where they have to make decisions and perform their tasks taking into account the new and different clinical situations that arise every day (Randerson et al., 2016) and the lack of technical and diagnostic equipment to better sustain the diagnosis and treatment of users. 
In relation to intrapreneurship construct, results suggest that health professionals in the primary health care sector show a 'venture behaviour' characterized by demand for new markets or communities for my organization $(\lambda=0.935)$ and development of activities that result in new projects within my organization $(\lambda=0,891)$ and a 'strategic renewal behavior' focusing on changing work practices $(\lambda=0.902)$ and the structure of the organization $(\lambda=0.899)$. This suggests that primary health care professionals have the ability to react to external and internal advances.

As for the innovation outputs construct, we found that the item with greater loading was "I have always implemented improvements in the places where I worked" $(\lambda=0.889)$ and "Many things created by me are used in our organization" $(\lambda=0.815)$. These findings imply that primary health care professionals are able to implement new ideas and are able to change services or processes within the organization. In this context, innovative primary health care professionals achieve innovative results, new services or new models.

The rational cognitive style of primary health care professionals has a positive relation with intrapreneurship $\left(\beta_{\text {Int.RCS }}=0.270 ; p<0.001\right)$, as well as the intuitive cognitive style $\left(\beta_{\text {Int.ICS }}=0.222 ; p=0.001\right)$. The importance of cognitive styles in the intrapreneur process has been addressed by some authors (e.g., Russel, 1999; Corbett \& Hmieleski, 2007). Primary health care professionals perform technical and precise tasks (e.g., vaccination), so what prevails from the development of an idea to its implementation takes into consideration a rational decision making based on the collection of information, identification of all the steps of the new task and deep knowledge of the process of their execution, i.e., these professionals make more use of the rational cognitive style in the intrapreneurial process. Because we are talking about frontline health professionals where automatic tasks predominate, the predominant cognitive style is the rational, but taking into account the turbulence and novelty of the pandemic we are experiencing, new clinical situations arise, whose resolution implies an intrapreneurial and innovative behavior on the part of these health professionals, using the combination of the two cognitive styles (Armstrong et al., 2011; Randerson et al., 2016).

The intrapreneurship of primary health care professionals promotes the innovation outputs $\left(\beta_{\text {Innov.Int }}=0.523 ; \mathrm{p}<0.001\right)$. Other empirical studies have identified this positive relationship between intrapreneurship and innovation (e.g., Wan et al., 2020a, 2020b).

Finally, intrapreneurship played a positive role between both rational cognitive styles and intuitive cognitive styles and innovation outputs $\left(\beta_{\text {oInnov.RCSInt }}=0.141\right.$; $\mathrm{p}=0.001$ vs. $\left.\beta_{\text {oInnov.ICSIInt }}=0.116 ; \mathrm{p}=0.006\right)$, this makes sense, since innovation outputs are the result of intrapreneurship (e.g., Letsie, 2017; Pandey et al., 2020) and this is positively influenced by cognitive styles, so the intrapreneurship of primary health professionals mediates the positive relationship between cognitive styles and innovation, and the rational cognitive style plays the most relevant role in this relationship. 


\section{Implications}

To the best knowledge of the authors, this study is the first to examine the role of cognitive styles on intrapreneurship - innovation outputs relationship. Our work on role cognitive styles has the potential to contribute to the ongoing debate regarding the domain of intrapreneurship and the issues of how opportunities for innovation arise within health care organizations. Our primary contribution to theory has been to highlight the importance of cognitive styles in intrapreneurial process and innovation within the context of primary health care organizations. Currently most of the literature focuses on the role of health care entrepreneurship from an external environmental perspective. This means the emphasis is on external stakeholders and how they influence entrepreneurial behaviour within a health care context. Our study suggests that intrapreneurship in terms of entrepreneurship occurring within a health care context is an important driver of innovation outputs. This means theory related to health care and entrepreneurship needs to incorporate more intrapreneurial processes within research practices. By doing this it will help to bridge the gap between internal entrepreneurial behaviour and external entrepreneurship performance. New research that focuses on the health care context should incorporate more detail about intrapreneurial entrepreneurial processes as it will help to discover new entrepreneurial practices.

Theoretically, this article contributed to the analysis of the evolution of the study of intrapreneurship. Firstly, the analysis of intrapreneurship models suggests the existence of predictors, such as the external environment, organizational behavior, the strategic vision of the firm and behavioral issues of individuals. By conducting empirical research involving a new predictor - cognitive styles - at the individual level, we provide further insight that must be in taken into account when drawing on new intrapreneurship models. Therefore, we provide a theoretical basis that managers can use when they seek to develop and apply strategies that improve intrapreneurship and innovation. Secondly, we research intrapreneurship at the individual level, which is particularly important as most research focuses on the organization. We show how the importance of intrapreneurship on innovation as a direct effect and as a mediator between cognitive styles and innovation. Our findings will enrich the current research about the relationship between intrapreneurship and innovation.

The examination of intrapreneurship with individual-level variables is particularly relevant for practitioners. Intrapreneurs can transform the organization with which they are engaged because, unlike other employees, they are self-motivated, passionate, innovative and enthusiastic about exploring new avenues. Therefore, scholarly examination of intrapreneurs would provide us valuable insights to pitch for the health care organization's ability to retain these employees. This study contributed to a better understanding about the role of cognitive styles in intrapreneurial decision-making of health care professionals. Health care organizations must formulate newer policies and approaches for boost a conducive work environment for such employees: intrapreneurs.

Intrapreneurship is, to a larger extent, dependent on the employees' ability, commitment and conviction toward innovation. Health care tasks or problems requiring 
innovation, this is critical in this period of full COVID 19 pandemic, thus it would make sense to choose teams based on their propensity to innovate and supporting in cognitive styles. If individual cognitive styles match task requirements, significant improvements can be realized in task outcomes.

Still on a practical level, the possibility of evaluating cognitive style in organizations has several uses: selecting employees and teams for certain health care tasks, adapting performance evaluation to the most prevalent cognitive style in each health care professional or creating training and exercises to lead these professionals to develop their less refined style. Since most health tasks require a mix of styles, the health care professional and the team must $\mathrm{b}$ and e chosen taking into account the versatility of cognitive styles for cognitive versatility (Aggarwal \& Woolley, 2019). Our study demonstrated that it is necessary to foster health professional's intrapreneurship, namely, to provide the autonomy to change norms and procedures and accept contributions of ideas that aim to improve health care tasks and services.

In terms of policy implications, our study suggests that health care practitioners can be entrepreneurial within their workplace practices. This is an interesting finding and particularly relevant in times of crisis such as the COVID-19 pandemic in which there is an emphasis on health care efficiency. This means government policy can focus on how to build intrapreneurial capacities by harnessing the collective knowledge of health care workers. They could do this by providing funding for commercialisation processes or education around entrepreneurship. This would help government health agencies to become more entrepreneurial and also to achieve better patient outcomes. As there has been an increased emphasis on public-private partnerships with regard to the health care industry, the findings of this study could help to build more beneficial collaborations. This would enable government and private health care agencies to collaborate on entrepreneurial practices. Thereby shifting the focus to cooperation rather than competition in the health care industry.

\section{Limitations, future research and conclusion}

Like any study, this research has some limitations. First, the Employee Intrapreneurship Measurement scale suggested by Gawke et al. (2019) is used, two-dimensional, with 17 items. This scale presents items that may not be relevant for measuring intrapreneurship of health professionals, especially those working in public organizations and in the primary health care sector, taking into account the particularity of the tasks they perform. Second, all measures were self-reported and hence subject to individual biases.

Further studies on the influence of individual-level variables on the behavior of employees, in this case health professionals, who are valued by organizations, would help both scholars and professionals to sharpen their selection and assignment of people to tasks and roles. The discovery in this study of the positive correlation between cognitive styles (rational and intuitive) with intra-entrepreneurship and innovation at the individual level is a step in that direction. Considering the results 
achieved in this study and the limitations identified, we consider relevant and attractive to present four proposals for future guidelines.

First, adapt and test a scale of intra-entrepreneurship adjusted to health professionals. Second, include some demographic variables, such as gender, since the discussion on differences in behavior taking into account gender in relation to cognitive styles, intra-entrepreneurship and innovation are present in some studies (e.g., Estelami \& Nejad, 2017). Third, to study the relationship between cognitive styles-innovative behavior-innovation. Along with intrapreneurship, the innovative behavior of health care professionals is extremely important to solve the problems that constantly arise in the provision of different tasks. Four, to collect information from more than one source, involving middle managers in the evaluation of innovative behavior and innovation outputs generated by their team members. Finally, data were collected only from primary health care professionals, so subsequent studies should test the conclusions of this paper in health professionals of diverse health organizations (e.g., hospitals, local unit of health, pharmacies, laboratories).

In sum, this study was motivated by the lack of empirical evidence in determining the linkages of cognitive style with intrapreneurship and innovation outputs. Our findings reveal that cognitive style plays a significant role in intrapreneurship and innovation outputs, mediated by intrapreneurship. In particular, health care professional with the rational cognitive style are likely to be more intrapreneur and innovative as compared to those with intuitive cognitive style.

Acknowledgements This work is supported by national funds, through the FCT-Portuguese Foundation for Science and Technology under the project UIDB/04011/2020.

\section{References}

Adomako, S., Danso, A., Uddin, M., \& Damoah, J. O. (2016). Entrepreneurs' optimism, cognitive style and persistence. International Journal of Entrepreneurial Behavior \& Research, 22(1), 84-108.

Ağca, V., Topal, Y., \& Kaya, H. (2012). Linking Intrapreneurship Activities to Multidimensional Firm Performance in Turkish Manufacturing Firms: An Empirical Study. International Entrepreneurship and Management Journal, 8(1), 15-33.

Aggarwal, I., \& Woolley, A. W. (2019). Team Creativity, Cognition, and Cognitive Style Diversity. Management Science, 65(4), 1586-1599.

Allinson, C. W., \& Hayes, J. (1996). The cognitive style index: A measure of intuition-analysis for organizational research. Journal of Management Studies, 33(1), 119-135.

Allinson, C. W., Chell, E., \& Hayes, J. (2000). Intuition and entrepreneurial behaviour. European Journal of Work and Organizational Psychology, 9(1), 31-43.

Alnuaimi, M. A., Alzoubi, H. M., \& Alnazer, N. N. (2017). Analysing the appropriate cognitive styles and its effect on strategic innovation in Jordanian universities. International Journal of Business Excellence, 13(1), 127-140.

Antoncic, B., \& R. D. \& Hisrich. (2001). Intrapreneurship: Construct Refinement and Cross-cultural Validation. Journal of Business Venturing, 16(5), 495-527.

Arbuckle, J. L. (2016). Amos Development Corporation, versão 24.

Armstrong, S. J., Cools, E. \& Sadler-Smith, E. (2011). Role of Cognitive Styles in Business and Management: Reviewing 40 Years of Research. International Journal of Management Reviews.

Bagozzi, R. P., \& Yi, Y. (1988). On the evaluation of structural equation models. Journal of the Academy of Marketing Science, 16(1), 74-94. 
Baldacchino, L. (2019). Intuition in Entrepreneurial Cognition. In. Caputo, A. \& Pellegrini, M. M. (eds.), The Anatomy of Entrepreneurial Decisions, Contributions to Management Science. (pp.2956). https://doi.org/10.1007/978-3-030-19685-1_3

Batra, S., \& Vohra, N. (2016). Exploring the linkages of cognitive style and individual innovativeness. Management Research Review, 39(7), 768-785.

Blanka, C. (2019). An individual-level perspective on intrapreneurship: A review and ways forward. Review of Managerial Science, 13(5), 919-961.

Bowen, D. E. (2016). The changing role of employees in service theory and practice: An interdisciplinary view. Human Resource Management Review, 26(1), 4-13.

Cadar, O., \& Badulescu, D. (2015). Entrepreneur, entrepreneurship and intrapreneurship. A literature review., Published in: The Annals of the University of Oradea, Economic Sciences, Vol. 2, No. XXIV (30 December 2015): pp. 658-664.

Camelo-Ordaz, C., Fernández-Alles, M., Ruiz-Navarro, J., \& Sousa-Ginel, E. (2012). The intrapreneur and innovation in creative firms. International Small Business Journal, 30(5), 513-535.

Caputo, A., \& Pellegrini, M. M. (Eds.). (2019). The Anatomy of Entrepreneurial Decisions: Past. Springer.

Chen, M. H., Chang, Y. Y., \& Lo, Y. H. (2015). Creativity cognitive style, conflict, and career success for creative entrepreneurs. Journal of Business Research, 68(4), 906-910.

Chin, W. W. (1998). The partial least squares approach to structural equation modeling. Modern Methods for Business Research, 295(2), 295-336.

Cohen, J. (1988). Statistical Power Analysis for the Behavioral Sciences-Second Edition. 12 Lawrence Erlbaum Associates Inc. Hillsdale, New Jersey, 13.

Cools, E., \& Broeck, H. V. (2007). Development and Validation of the Cognitive Style Indicator. The Journal of Psychology: Interdisciplinary and Applied, 141(4), 359-387.

Corbett, A. C., \& Hmieleski, K. M. (2007). The conflicting cognitions of corporate entrepreneurs. Entrepreneurship Theory and Practice, 31(1), 103-121.

Côté-Boileau, É., Denis, J.-L., Callery, B., \& Sabean, M. (2019). The unpredictable journeys of spreading, sustaining and scaling healthcare innovations: A scoping review. Health Research Policy and Systems, 17(1), 84.

Covin, J. G., \& Slevin, D. P. (1991). A conceptual model of entrepreneurship as firm behavior. Entrepreneurship Theory and Practice, 16(1), 7-26.

Croskerry, P. (2009). A universal model of diagnostic reasoning. Academic Medicine, 84(8), 1022-1028.

Deprez, J., Cools, E., Robijn, W., \& Euwema, W. (2019). Choice for an Entrepreneurial Career: Do Cognitive Styles Matter? Entrepreneurship Research Journal. https://doi.org/10.1515/erj-2019-0003

Djulbegovic, B., Beckstead, J. W., Elqayam, S., Reljic, T., Hozo, I., Kumar, A., \& Paidas, C. (2014). Evaluation of physicians' cognitive styles. Medical Decision Making, 34(5), 627-637.

Drucker, P. (2014). The Practice of Management. Routledge.

Emilsson, M., Ernstson, U., Gustavsson, L., \& Svensson, A. (2020). Sustainable Innovations in Small Enterprises for the Transformation of the Primary Healthcare Sector. Sustainability, 12(16), 6391. https://doi.org/10.3390/su12166391

Epstein, S., Pacini, R., Denes-Raj, V., \& Heier, H. (1996). Individual differences in intuitive-experiential and analytical-rational thinking styles. Journal of Personality and Social Psychology, 71(2), 390-405.

Estelami, H., \& Nejad, M. (2017). The impact of cognitive style, entrepreneurial attitudes and gender on competitive price responses. Journal of Product \& Brand Management, 26(7), 759-770.

Falk, R. F., \& Miller, N. B. (1992). A Primer for Soft Modeling. University of Akron Press.

Fornell, C., \& Larcker, D. F. (1981). Evaluating structural equation models with unobservable variables and measurement error. Journal of Marketing Research, 18(1), 39-50.

Foss, N. J., \& Klein, P. G. (2015). Introduction to a forum on the judgment-based approach to entrepreneurship: Accomplishments, challenges, new directions. Journal of Institutional Economics, 11(3), 585-599.

Franić, S., \& Drnovšek, M. (2019). The role of regulatory focus and cognitive style in business angels' evaluation of an investment opportunity. Venture Capital, 21(4), 353-377.

Galván-Vela, E., Arango Herrera, E., Sorzano Rodríguez, D. M., \& Ravina-Ripoll, R. (2021). State-ofthe-Art Analysis of Intrapreneurship: A Review of the Theoretical Construct and Its Bibliometrics. Journal of Risk and Financial Management, 14(4), 148. 
Gartner, W. B., \& Shane, S. A. (1995). Measuring entrepreneurship over time. Journal of Business Venturing, 10(4), 283-301.

Gawke, J. C., Gorgievski, M. J., \& Bakker, A. B. (2018). Personal costs and benefits of employee intrapreneurship: Disentangling the employee intrapreneurship, well-Being, and job performance relationship. Journal of Occupational Health Psychology, 23(4), 508-519.

Gawke, J. C., Gorgievski, M. J., \& Bakker, A. B. (2019). Measuring intrapreneurship at the individual level: Development and validation of the Employee Intrapreneurship Scale (EIS). European Management Journal, 37(6), 806-817.

Gefen, D., Rigdon, E. E., \& Straub, D. (2011). Editor's comments: an update and extension to SEM guidelines for administrative and social science research. MIS Quarterly, iii-xiv.

Geisser, S. (1974). A predictive approach to the random effect model. Biometrika, 61(1), 101-107.

Hair, J. F., Ringle, C. M., \& Sarstedt, M. (2011). PLS-SEM: Indeed a silver bullet. Journal of Marketing Theory and Practice, 19(2), 139-152.

Hair, J. F., Ringle, C. M., \& Sarstedt, M. (2012). Partial least squares: The better approach to structural equations modeling? Journal of Long Range Planning, 45(5-6), 312-319.

Hair, J. F., Sarstedt, M., Ringle, C. M., \& Pieper, T. (2013). The use of partial least squares structural equation modeling in strategic management research: A review of past practices and future applications. Long Range Planning, 45(5-6), 320-340.

Hayes, A. F. (2009). Beyond Baron and Kenny: Statistical mediation analysis in the new millennium. Communication Monographs, 76(4), 408-420.

Howell, J. M., Shea, C. M., \& Higgins, C. A. (2005). Champions of product innovations: Defining, developing, and validating a measure of champion behavior. Journal of Business Venturing, 20(5), 641-661.

Lages, M., Marques, C. S., Ferreira, J. J., \& Ferreira, F. A. (2017). Intrapreneurship and firm entrepreneurial orientation: Insights from the health care service industry. International Entrepreneurship and Management Journal, 13(3), 837-854.

Letsie, T. M. (2017). Antecedents of intrapreneurship practice among public hospital unit nurse managers. International Journal of Africa Nursing Sciences, 100(7), 126-135.

Lomberg, C., Kollmann, T., \& Stöckmann, C. (2017). Different Styles for Different Needs - The Effect of Cognitive Styles on Idea Generation. Creativity and Innovation Management, 26(1), 49-59.

Lukeš, M., \& Stephan, U. (2017). Measuring employee innovation: A review of existing scales and the development of the innovative behavior and innovation support inventories across cultures. International Journal of Entrepreneurial Behavior \& Research, 23(1), 136-158.

Machon, M., Cundy, D., \& Case, H. (2019). Innovation in nursing leadership: A skill that can be learned. Nursing Administration Quarterly, 43(3), 267-273.

Marques, C. S., Marques, C. P., Ferreira, J. J., \& Ferreira, F. A. (2019). Effects of traits, self-motivation and managerial skills on nursing intrapreneurship. International Entrepreneurship and Management Journal, 15(3), 733-748.

Marques, C. S., Valente, S., \& Lages, M. (2018). The influence of personal and organisational factors on entrepreneurship intention: An application in the health care sector. Journal of Nursing Management, 26(6), 696-706.

Marvel, M. R., Griffin, A., Hebda, J., \& Vojak, B. (2007). Examining the technical corporate entrepreneurs' motivation: Voices from the field. Entrepreneurship Theory and Practice, 31(5), 753-768.

Molaei, R., Zali, M. R., Mobaraki, M. H., \& Farsi, J. Y. (2014). The impact of entrepreneurial ideas and cognitive style on students entrepreneurial intention. Journal of Entrepreneurship in Emerging Economies, 6(2), 140-162.

Moulton, C. A., Regehr, G., Mylopoulos, M., \& MacRae, H. M. (2007). Slowing down when you should. A New Model of Expert Judgment, 82.

Neessen, P. C., Caniëls, M. C., Vos, B., \& De Jong, J. P. (2019). The intrapreneurial employee: Toward an integrated model of intrapreneurship and research agenda. International Entrepreneurship and Management Journal, 15(2), 545-571.

Pandey, J., Gupta, M., \& Hassan, Y. (2020). Intrapreneurship to engage employees: Role of psychological capital. Management Decision. https://doi.org/10.1108/MD-06-2019-0825

Parker-Tomlin, M., Boschen, M., Glendon, I., \& Morrissey, S. (2018). Factors influencing health practitioners' cognitive processing and decision-making style. Journal of Interprofessional Care, 33(5), $546-557$.

Quirk, M. (2006). Intuition and metacognition in medical education: Keys to developing expertise. Springer publishing company. 
Randerson, K., Degeorge, J.-M., \& Fayolle, A. (2016). Entrepreneurial opportunities: How do cognitive styles and logics of action fit in? International Journal of Entrepreneurship and Small Business, 27(1), 19-39.

Rauch, A. (2010). Dispositions of entrepreneurs: Exploring entrepreneurs' personality characteristics. In: M. Lukeš and M. Laguna (Eds.) Entrepreneurship: A Psychological Approach (pp. 36-54). Prague: Oeconomica.

Reuther, K., Schumann, C. A., Borodzicz, E. P., \& Johnston, J. B. (2017). Intrapreneurship employees' attitude and the appropriate working environment. In 2017 International Conference on Engineering, Technology and Innovation (ICE/ITMC) (pp. 271-281). IEEE.

Ringle, C. M., Wende, S., \& Becker, J.-M. (2015). SmartPLS 3. Bönningstedt: SmartPLS. Retrieved from http://www.smartpls.com

Rufaidah, P. (2017). Branding strategy development based on innovative behaviour. International Journal of Business and Globalisation, 18(3), 396-416.

Russell, R. D. (1999). Developing a process model of intrapreneurial systems: A cognitive mapping approach. Entrepreneurship Theory and Practice, 23(3), 65-84.

Stone, M. (1974). Cross-validatory choice and assessment of statistical predictions. Journal of the Royal Statistical Society: Series B (methodological), 36(2), 111-133.

Tay, S. W., Ryan, P., \& Ryan, C. A. (2016). Systems 1 and 2 thinking processes and cognitive reflection testing in medical students. Canadian Medical Education Journal, 7(2), e97.

Tenenhaus, M., Vinzi, V. E., Chatelin, Y. M., \& Lauro, C. (2005). PLS path modeling. Computational Statistics \& Data Analysis, 48(1), 159-205.

Tognazzo, A., Sassetti, S., Caputo, A., \& Pellegrini, M. (2020). Editorial special issue entrepreneurial decision-making and behavior. Journal of Small Business \& Entrepreneurship, 32(1), 1-7.

Wan, W., Liu, L. \& Wang, X. (2020). How user-driven innovation and employee intrapreneurship promote platform enterprise performance. Management Decision. https://doi.org/10.1108/MD-06-2019-0701

Wan, W., Liu, L., \& Wang, X. (2020b). How user-driven innovation and employee intrapreneurship promote platform enterprise performance. Management Decision., 58(12), 2705-2723.

Wojtczuk-Turek, A., \& Turek, D. (2015). Innovative behaviour in the workplace: The role of HR flexibility, individual flexibility and psychological capital: The case of Poland. European Journal of Innovation Management, 18(3), 397-419.

Yang, K., Zhou, L., Wang, Z., Lin, C., \& Luo, Z. (2019). Humble leadership and innovative behaviour among Chinese nurses: The mediating role of work engagement. Journal of Nursing Management, 27(8), 1801-1808.

Zahra, S. A. (1995). Corporate Entrepreneurship and Financial Performance: The Case of Management Leveraged Buyouts. Journal of Business Venturing, 10(3), 225-247.

Zhang, X., \& Bartol, K. M. (2010). Linking empowering leadership and employee creativity: The influence of psychological empowerment, intrinsic motivation, and creative process engagement. Academy of Management Journal, 53(1), 107-128.

Publisher's Note Springer Nature remains neutral with regard to jurisdictional claims in published maps and institutional affiliations.

\title{
Authors and Affiliations
}

\section{Carla S. Marques ${ }^{1} \cdot$ Cândido Lopes $^{2} \cdot$ Vitor Braga $^{3} \cdot$ Vanessa Ratten $^{4}(0$. Gina Santos ${ }^{5}$}

\author{
Carla S. Marques \\ smarques@utad.pt \\ Cândido Lopes \\ clopesmm@gmail.com \\ Vitor Braga \\ vbraga@estg.ipp.pt \\ Gina Santos \\ gina.santos@utad.pt
}


1 Department of Economics, Sociology and Management \& CETRAD - Research Unit, University of Trás-Os-Montes and Alto Douro, Vila Real, Portugal

2 ACES Tâmega III- Vale Sousa Norte, Penafiel, Portugal

3 School of Technology and Management \&, Institute Polytechnic of Porto, CIICESI, Porto, Portugal

4 Department of Management, Sport and Tourism, La Trobe University, La Trobe Business School, Melbourne, Australia

5 University of Trás-Os-Montes and Alto Douro \& CETRAD - Research Unit, Vila Real, Portugal 